\title{
Genetic Variability of Passion Fruit Multispecific Hybrids and Their Respective Wild Parents Determined by Microsatellite Markers
}

\author{
Mara Cecília de Mattos Grisi ${ }^{1,2}$, Fábio Gelape Faleiro ${ }^{1}$, Nilton Tadeu Vilela Junqueira ${ }^{1}$ \\ \& Jamile da Silva Oliveira ${ }^{1}$ \\ ${ }^{1}$ Brazilian Agricultural Research Corporation, Embrapa Cerrados, Planaltina, Brazil \\ ${ }^{2}$ Department of Agronomy, Campus Universitário Darcy Ribeiro, University of Brasília, Brasília, Brazil \\ Correspondence: Mara Cecília de Mattos Grisi, Embrapa Cerrados, Planaltina, DF 73310-970, Brazil. Tel: \\ 55-619-9816-6995. E-mail: maragrisi@hotmail.br
}

Received: April 14, 2019

doi:10.5539/jas.v11n10p302
Accepted: May 6, 2019 Online Published: July 15, 2019

URL: https://doi.org/10.5539/jas.v11n10p302

\begin{abstract}
The Passiflora genus comprises more than 500 species that are used for food, industrial, ornamental, and pharmaceutical purposes. The sour passion fruit (P. edulis Sims) has low genetic variability for disease resistance, and the use of wild species in the cross-breeding basis is a promising alternative for introgression of resistance genes. The objective of this study was to characterize multispecific hybrids and wild materials with potential to be used as parents in passion fruit genetic breeding programs, using microsatellite markers. Genomic DNA from 33 accessions was extracted and analyzed using 23 microsatellite markers, which were used to estimate the genetic dissimilarities among accessions. The genetic dissimilarity matrices were used to perform clustering analysis by dendrogram using the Unweighted Pair-Group Method as grouping criterion and by graphic dispersion based on multidimensional scale, using the principal coordinates method. Genetic distances between accessions ranged from 0.067 to 1.00 . The markers indicated genetic variability among the studied accessions and also the efficiency of the recurrent genome recovery within the backcross program. The genetic structure among the accessions shows the clustering tendency between the wild accessions of $P$. hatschbachii and $P$. quadrifaria and the accessions obtained by crossing these species. The same occurred for $P$. incarnata and $P$. edulis accessions. The knowledge generated by the molecular characterization provides information on the diversity of accessions and contributes to the work of breeders in the selection of parents.
\end{abstract}

Keywords: SSR, clustering analysis, passion fruit, wild species, genetic breeding

\section{Introduction}

Passiflora L. is the largest genus of the Passifloraceae family, comprising approximately 525 species (Bernacci, Vitta, \& Bakker, 2003). The majority of these species is found in the Americas, especially South America, where Colombia and Brazil are the largest diversity centers with nearly 240 native species (Bernacci et al., 2003; Ulrich \& MacDougal, 2004; Imig, Milward-de-Azevedo, \& Cervi, 2018). Most species are popularly known as passion fruit. Some of them have commercial and pharmacological value and are cultivated on a large scale for consumption or as ornamental plants (Imig et al., 2018). The Passiflora genus contains the largest number of species within the Passifloraceae family. Its taxonomy recognizes five subgenuses: Passiflora sub. Passiflora, P. sub. Decaloba (DC) Rchb., P. sub. Astrophea (DC) Mast., P. sub. Deidamioides (Harms) Killip (Feuillet \& MacDougal, 2004), and P. sub. Tetrapathea (DC) P. S. Green, included by Krosnick, Ford, \& Freudenstein, (2009).

The sour passion fruit (Passiflora edulis L.) is an allogamous species with great variability of shapes and colors of fruits and flowers. It is the cultivated species of highest economic importance. Its edible fruits are widely used in culinary and in preparations of alcoholic beverages and juices (Vanderplank, 1996). This species also has medicinal importance in the manufacturing of calming agents. Additionally, its crushed seeds are used as a vermifuge (Bernacci et al., 2003).

However, significant losses are observed with crop expansion in Brazil due to the infection by several plant pathogens, such as Xanthomonas axonopodis pv. passiflorae, Cowpea aphid-borne mosaic virus (CABMV), Colletotrichum gloeosporioides, Meloidogyne spp., Fusarium oxysporum f. sp. passiflorae, and F. solani 
(Junqueira, Braga, Faleiro, Peixoto, \& Bernacci, 2005). As a consequence, the development of disease resistant varieties is critical for this crop since it reduces production costs, increases fruit market quality, and contributes to the environmental preservation and sustainability of passion fruit cultivation in the country (Quirino, 1998).

Considering the economic and social importance of this crop, the breeding program developed by the Brazilian Agricultural Research Corporation (Embrapa Cerrados-CPAC) and partners performs inter and intraspecific crosses to obtain disease resistant hybrids. Crosses are performed between species that are compatible to the commercial P. edulis, such as $P$. setacea DC, P. quadrifaria Vanderpl., P. incarnata L., P. caerulea L., $P$. hatschbachii Cervi, among others, aiming the introduction of desirable characteristics, especially disease resistance (Junqueira et al., 2005). The molecular characterization of accessions used in the Passiflora breeding program contributes to a better understanding of plant diversity and genetic background, which are crucial information for parent selection by breeders (Segura, D’Eeckenbrugge, Bohorquez, Ollitrault, \& Tohme, 2002; Viana et al., 2003).

The genetic diversity of Passiflora has been assessed by morphological descriptors (Plotze et al., 2005; Viana, Souza, Araújo, Corrêa, \& Ahnert, 2010; Ramaiya, Bujang, \& Zakaria, 2014; Oliveira, Faleiro, Junqueira, \& Viana, 2016; Pérez \& D’Eeckenbrugge, 2017), agronomic traits (Meletti, Soares-Scot, \& Bernacci, 2005; Cerqueira-Silva, Moreira, Figueira, Corrêa, \& Oliveira, 2008; Abreu, Peixoto, Vilela, \& Figueiredo, 2009), and ecological descriptors (Segura, D'Eeckenbrugge, López, Grum, \& Guarino, 2003). DNA polymorphism in Passiflora spp. has been detected by different types of molecular markers, such as restriction enzymes (cpDNA; Yockteng \& Nadot, 2004; Paikrao et al., 2010), Inter Simple Sequence Repeats (ISRR; Santos et al., 2011, Oliveira, Faleiro, Junqueira, Fonseca, \& Araya, 2019), Random Amplified Polymorphic DNA (RAPD; Fajardo et al., 1998; Aukar et al., 2002; Crochemore, Molinari, \& Vieira, 2003; Bellon et al., 2007; Cerqueira-Silva et al., 2010; Oliveira et al., 2019), Amplified Fragment Length Polymorphism (AFLP; Segura et al., 2002), Internal Transcribed Spacer (ITS; Muschner et al., 2003; Mäder et al., 2010; Bellon, 2014; Ramaiya et al., 2014), and Simple Sequence Repeats (SSR/microsatellites; Oliveira et al., 2005; Cerqueira-Silva et al., 2012; Cerqueira-Silva et al., 2014; Paiva et al., 2014a; Araya et al., 2017).

Despite the high variability found in morphological and agronomic evaluations, as well as in most studies using molecular markers, the use of microsatellite markers in $P$. edulis has generally presented low levels of polymorphism (Oliveira et al., 2005; Cerqueira-Silva et al., 2012, 2014; Ortiz et al., 2012). High reproducibility and polymorphism, codominance, and multiallelism (Litt \& Luty, 1989; Powell et al., 1996) are advantages of microsatellites when compared to other types of molecular markers. However, less than 200 microsatellite markers were available for genetic studies in P. edulis by 2017 (Oliveira et al., 2005; Oliveira, 2006; Cerqueira-Silva et al., 2014), most of them based on imperfect and compound motifs (Domaniç \& Preparata, 2007; Lim, Kwoh, Hsu, \& Wirawan, 2013). Currently, more than 1,000 microsatellite markers are available for $P$. edulis, considering the recent work of Araya et al. (2017), in which primer pairs for 816 perfect microsatellite regions were developed. The prefix "BrPe" was given to this new set of SSR markers. The "BrPe" microsatellites proved to be highly polymorphic, with high values for PIC (polymorphic information content), Ho (observed heterozygosity), and allele number (Araya et al., 2017). In addition, it has a high transferability to other species of the Passiflora genus, showing a potential to be used in genetic analyses of a wide number of Passiflora species.

Therefore, this work aimed to characterize 33 passion fruit accessions, which include multispecific hybrids and their respective wild parents, through microsatellite markers. The knowledge generated by the molecular characterization aims to provide information about the genotype diversity and to contribute to the work of breeders in the selection of parents.

\section{Method}

\subsection{Plant Material and DNA Extraction}

Fresh young leaves from 33 accessions from the Embrapa Cerrados germplasm bank, Planaltina, DF, Brazil, were used for DNA extraction with the standard CTAB protocol, with modifications (Faleiro, Faleiro, Cordeiro, $\&$ Karia, 2003). The DNA concentration was estimated by $1 \%$ agarose gel electrophoresis, and the fluorescence intensities of each sample stained with ethidium bromide were compared with different Lambda DNA standards. Each sample was then diluted to the concentration of $3.0 \mathrm{ng} / \mu \mathrm{l}$.

The accessions used in the present study are described in Table 1 . These accessions represent a group of 18 interspecific hybrids; 11 plants of different species used as parents $(P$. aff. amethystina "macrocarpa", $P$. caerulea L., P. edulis Sims, P. hatschbachii Cervi, P. incarnata L., P. quadrifaria Vanderpl, P. setacea DC, and $P$. tholozanii Sims); 1 accession of the MSC matrix ("Marília Seleção Cerrado"); and 3 different accessions of $P$. 
edulis "roxo típica". The P. edulis "roxo típica" is an autogamous variety of little-known phylogeny that produces small purple peel fruits. All 33 accessions were genotyped with 23 microsatellite markers developed by Araya et al. (2017). These microsatellites were chosen based on their amplification quality and on the PIC obtained by Araya et al. (2017).

Table 1. Passion fruit (Passiflora spp.) accessions from the Embrapa Cerrados Germplasm Bank genotyped with microsatellite markers

\begin{tabular}{|c|c|c|}
\hline Number & Accession & Genetic origin \\
\hline 1 & PL $3 \times$ GA (T4R4PL1) & {$[(P$. hatschbachii $\times P$. quadrifaria $) \times P$. incarnata $] \times P$. edulis $(\mathrm{BC} 3) / \mathrm{CPAC}$ experimental field } \\
\hline 2 & ML 1 & $(P$. edulis $\times P$. amethystina $) \times P$. edulis $(\mathrm{BC} 5) /$ CPAC Greenhouse \\
\hline 3 & ML 2 & {$[(P$. edulis $\times P$. amethystina $) \times P$. edulis $(\mathrm{BC} 5) /$ CPAC Greenhouse } \\
\hline 4 & PL 2 & {$[(P$. hatschbachii $\times$ P. quadrifaria $) \times P$. incarnata $] \times P$. edulis $(\mathrm{BC} 1) / \mathrm{CPAC}$ Greenhouse } \\
\hline 5 & MEAM-3 & $(P$. edulis $\times$ P. amethystina $) \times P$. edulis $(\mathrm{BC} 3) / \mathrm{CPAC}$ Greenhouse \\
\hline 6 & GX DF & P. edulis/CPAC Greenhouse \\
\hline 7 & GX SB & P. edulis/CPAC Greenhouse \\
\hline 8 & PL 6 & {$[(P$. hatschbachii $\times$ P. quadrifaria $) \times P$. incarnata $] \times P$. edulis $(\mathrm{BC} 2) / \mathrm{CPAC}$ Greenhouse } \\
\hline 9 & PL 1 MEAM-2 & {$[(P$. edulis $\times P$. amethystina $) \times P$. edulis $(\mathrm{BC} 1)] \times P$. incarnata $/$ CPAC Greenhouse } \\
\hline 10 & PL 4 (Longão flor azul) & $(P$. edulis $\times$ P. incarnata $) \times P$. edulis $(\mathrm{BC} 3) / \mathrm{CPAC}$ Greenhouse \\
\hline 11 & PL 3 & {$[(P$. hatschbachii $\times$ P. quadrifaria $) \times P$. incarnata $] \times P$. edulis $(\mathrm{BC} 1) /$ CPAC Greenhouse } \\
\hline 12 & PL 5 & {$[(P$. hatschbachii $\times P$. quadrifaria $) \times P$. incarnata $] \times P$. edulis $(\mathrm{BC} 2) / \mathrm{CPAC}$ Greenhouse } \\
\hline 13 & LD3 & P. edulis—flowers with 3 stigmas/BAG 162 \\
\hline 14 & 325 & P. caerulea $\times$ P. edulis $(\mathrm{BC} 4) / \mathrm{BAG} 167$ \\
\hline 15 & LD4 & P. edulis—flowers with 4 stigmas/BAG 72 \\
\hline 16 & Vermelhão & P. caerulea $\times$ P. edulis $(\mathrm{BC} 5) / \mathrm{CPAC}$ Greenhouse \\
\hline 17 & P. caerulea & Wild species/BAG 111 \\
\hline 18 & MEAM-1 & {$[(P$. edulis $\times P$. amethystina $) \times P$. edulis $(\mathrm{BC} 1)] \times P$. incarnata $/ \mathrm{BAG}$} \\
\hline 19 & P. aff. amethystina & wild species/CPAC Greenhouse \\
\hline 20 & P. edulis $\times$ P. incarnata & $(P$. edulis $\times P$. incarnata $) \times P$. edulis $(\mathrm{BC} 2) / \mathrm{BAG}$ line 10 \\
\hline 21 & P. incarnata & Wild species/BAG \\
\hline 22 & Rosa Púrpura $\times P$. edulis & {$[(P$. hatschbachii $\times P$. quadrifaria $) \times P$. incarnata $] \times P$. edulis $/$ CPAC Greenhouse } \\
\hline 23 & Rosa Púrpura & $(P$. hatschbachii $\times P$. quadrifaria $) \times P$. incarnata $/ \mathrm{BAG} 84$ \\
\hline 24 & P. setacea $\times$ P. edulis & P. setacea $\times$ P. edulis $/$ CPAC experimental field \\
\hline 25 & P. setacea & Wild species/CPAC experimental field \\
\hline 26 & P. hatschbachii & Wild species/BAG 131 \\
\hline 27 & P. hatschbachii $\times$ P. quadrifaria & P. hatschbachii $\times$ P. quadrifaria $/ \mathrm{BAG}$ \\
\hline 28 & P. quadrifaria & Wild species/CPAC experimental field \\
\hline 29 & P. tholozanii & BAG 97/Manaus-Amazonas/ Brazil \\
\hline 30 & MSC & P. edulis/CPAC experimental field \\
\hline 31 & P. edulis "roxo típica" (PL1) & Wild species/CPAC experimental field \\
\hline 32 & P. edulis "roxo típica" (PL2) & Wild species/CPAC experimental field \\
\hline 33 & P. edulis "roxo típica" (PL3) & Wild species/CPAC experimental field \\
\hline
\end{tabular}

Note. CPAC: Embrapa Cerrados; BC: backcross; BAG: Germplasm Genetic Bank.

\subsection{Microsatellite Marker PCR Assays}

Multiplex panels for simultaneous evaluation of microsatellite markers were designed using the Multiplex Manager program (Holleley \& Geerts, 2009). PCR assays were performed in a final volume of $5 \mu$ containing 5 $\eta$ g of genomic DNA, 1X QIAGEN Multiplex PCR Kit Master Mix (QIAGEN), 0.5X Q-Solution (QIAGEN), and $0.2 \mu \mathrm{M}$ of each primer. Reactions were performed on a Veriti ${ }^{\mathrm{TM}}$ Thermal Cycler (Applied Biosystems, USA) using the following amplification program: $95{ }^{\circ} \mathrm{C}$ for 15 minutes; 35 cycles at $94{ }^{\circ} \mathrm{C}$ for 30 seconds; 55,57 or $60{ }^{\circ} \mathrm{C}$ for 90 seconds; $72{ }^{\circ} \mathrm{C}$ for 60 seconds; and a final extension step at $60{ }^{\circ} \mathrm{C}$ for $60 \mathrm{~min}$. Afterwards, $9 \mu \mathrm{l}$ of Hi-Di ${ }^{\text {TM }}$ Formamide (Applied Biosystems, USA) and $1 \mu \mathrm{l}$ of ROX-labeled internal size standard were added to $1 \mu \mathrm{l}$ of the PCR product. Samples were then subjected to denaturation at $94{ }^{\circ} \mathrm{C}$ for 5 minutes. The denatured product was injected into an ABI3730 automated sequencer (Applied Biosystems, USA). Identification of the alleles according to size and genotyping was performed using the GeneMapper ${ }^{\circledR}$ software v. 4.1 (Applied 
Biosystems, USA). Automated allelic binning was performed with the Tandem software (Matschiner \& Salzburger, 2009).

Polymorphism, number of alleles, expected and observed heterozygosities (He and Ho, respectively), PIC values, and other statistics were estimated by the CERVUS program (Marshall, Slate, Kruuk, \& Pemberton, 1998). He values were determined as the probability of an individual being heterozygous at a locus according to its allele frequencies.

The generated genotyping data were converted into a binary matrix data. The genetic dissimilarity among accessions was estimated based on the complement of the Nei and Li's similarity coefficient, using the Genes software (Cruz, 2013). The genetic dissimilarity matrix was used for clustering analysis by dendrogram using the Unweighted Pair-Group Method (UPGMA) as a clustering criterion. In addition, graphical dispersion was generated based on multidimensional scale, using the principal coordinates method, and with the aid of the SAS (SAS Institute Inc., 2008) and Statistica (StatSoft Inc, 2005) programs.

\section{Results and Discussion}

The 23 microsatellite markers were polymorphic and allowed the detection of 147 alleles (Table 2). The number of alleles observed for all microsatellite markers ranged from 2 to 10 , with a mean of 6.39 alleles per locus. Marker He varied between 0.36 and 0.87 , with a mean value of 0.65 . Ho values ranged from 0.09 to 0.87 , with a mean of 0.35 . PIC varied from 0.32 to 0.83 , with a mean value of 0.59 (Table 2). PIC values above 0.5 are classified as highly informative; values ranging from 0.25 to 0.5 are considered as moderately informative; those below 0.25 are classified as less informative (Botstein, White, Skolnick, \& Davis, 1980). The amplicon size produced by each microsatellite marker is shown in Table 2. 
Table 2. Descriptive statistics of Passiflora edulis microsatellite markers

\begin{tabular}{|c|c|c|c|c|c|c|c|c|c|}
\hline \# & Marker & Primer Sequences 5'-3' & Repeat Motif & $\mathrm{Ta}\left({ }^{\circ} \mathrm{C}\right)$ & Allele Number & Allele Size (bp) & $\mathrm{He}$ & Ho & PIC \\
\hline 1 & $\mathrm{BrPe} 0032$ & $\begin{array}{l}\text { F:TTGCACAATGACCAATGTTGT } \\
\text { R:CTGAGCACCTTGTCAAAATACA }\end{array}$ & (AT) 13 & 60 & 7 & $134-152$ & 0.71 & 0.23 & 0.67 \\
\hline 2 & $\mathrm{BrPe} 0028$ & $\begin{array}{l}\text { F:CAAAAGGAACAGGGAAGA } \\
\text { R:GAAAGAGAGAAAGACAGAGA }\end{array}$ & $(\mathrm{TA}) 6$ & 55 & 8 & $91-105$ & 0.81 & 0.41 & 0.77 \\
\hline 3 & $\mathrm{BrPe} 0024$ & $\begin{array}{l}\text { F:CCCTACCTTTCTCTGCTT } \\
\text { R:CATCTCCTCTATCTCCTTC }\end{array}$ & (TC)7 & 55 & 4 & $221-231$ & 0.63 & 0.11 & 0.55 \\
\hline 4 & BrPe0031 & $\begin{array}{l}\text { F:AGGTCGGTGGGTGTGTTTAG } \\
\text { R:CATTCAACTCCCCAAAAGGT }\end{array}$ & $(\mathrm{TA}) 9$ & 60 & 8 & $130-152$ & 0.66 & 0.52 & 0.61 \\
\hline 5 & $\mathrm{BrPe} 0014$ & $\begin{array}{l}\text { F:AATATGGCTGGGGAAAAC } \\
\text { R:TTCCTGTCTTTGGACCTT }\end{array}$ & $(\mathrm{AG}) 7$ & 57 & 3 & $214-222$ & 0.36 & 0.19 & 0.32 \\
\hline 6 & $\mathrm{BrPe} 0033$ & $\begin{array}{l}\text { F:GCCATGAGAGACTTGGGAGA } \\
\text { R:CGGTTGCCAAAAAGAAGAGA }\end{array}$ & $(\mathrm{AT}) 8$ & 60 & 6 & $232-252$ & 0.77 & 0.12 & 0.71 \\
\hline 7 & $\mathrm{BrPe} 0038$ & $\begin{array}{l}\text { F:TTTCAACTTTTCGTGTGTGC } \\
\text { R:TGTTGTTGCTTGGAAGGATG }\end{array}$ & $(\mathrm{AT}) 6$ & 60 & 6 & $152-168$ & 0.65 & 0.23 & 0.60 \\
\hline 8 & $\mathrm{BrPe} 0042$ & $\begin{array}{l}\text { F:CATGCATTCATTTGTTTTTCTTG } \\
\text { R:GATGCTGGGAAAAAGAGTGC }\end{array}$ & $(\mathrm{AT}) 8$ & 60 & 8 & $133-167$ & 0.66 & 0.21 & 0.59 \\
\hline 9 & BrPe0003 & $\begin{array}{l}\mathrm{F}: \text { CTTTCTCTCCСТАТАCCC } \\
\text { R:CCCTCCATAATCACATAAC }\end{array}$ & (TC)11 & 55 & 8 & $273-295$ & 0.77 & 0.30 & 0.72 \\
\hline 10 & $\mathrm{BrPe} 0043$ & $\begin{array}{l}\text { F:TCATACATGGATGTCAAATCGATAC } \\
\text { R:GCGGACCAAGAAAATTCAAA }\end{array}$ & $(\mathrm{AT}) 8$ & 60 & 3 & 199-207 & 0.47 & 0.39 & 0.41 \\
\hline 11 & BrPe0006 & $\begin{array}{l}\text { F:AAGGAAAAGAACAGCCTCA } \\
\text { R:CGCTCTCAAATCAGTCAAA }\end{array}$ & (TC) 10 & 55 & 9 & 183-199 & 0.83 & 0.23 & 0.79 \\
\hline 12 & $\mathrm{BrPe} 0002$ & $\begin{array}{l}\text { F:AAAGCCCAGATGAAGTGAA } \\
\text { R:GGCTCCAATCAGAAGTGT }\end{array}$ & (AG)12 & 55 & 6 & $160-182$ & 0.72 & 0.34 & 0.67 \\
\hline 13 & $\mathrm{BrPe} 0021$ & $\begin{array}{l}\text { F:ACTTCCTCATCATTCG } \\
\text { R:GCTATGCCTCTTTTTG }\end{array}$ & (TA)7 & 55 & 8 & $147-171$ & 0.66 & 0.22 & 0.61 \\
\hline 14 & $\mathrm{BrPe} 0023$ & $\begin{array}{l}\text { F:AGATACCACACCCAATAG } \\
\text { R:TTGGAGTTGTTGGGGA }\end{array}$ & (CT)7 & 55 & 3 & $116-120$ & 0.48 & 0.09 & 0.42 \\
\hline 15 & $\mathrm{BrPe} 0037$ & $\begin{array}{l}\text { F:TGATAATGCAGCGAAAGAGC } \\
\text { R:TCACACTCCATTTGCTCTGC }\end{array}$ & (TG)6 & 60 & 9 & $214-238$ & 0.80 & 0.87 & 0.76 \\
\hline 16 & $\mathrm{BrPe} 0010$ & $\begin{array}{l}\text { F:GAAGAAAAAAGGGCTTG } \\
\text { R:GTTAGGGTTTGGAGGA }\end{array}$ & (TC) 9 & 55 & 10 & 189-209 & 0.75 & 0.35 & 0.72 \\
\hline 17 & BrPe0001 & $\begin{array}{l}\text { F:GTTGAGAGGATTGTGTTTG } \\
\text { R:ATGGTAGAGGAGGAGAGA }\end{array}$ & (CT) 14 & 55 & 5 & $149-159$ & 0.61 & 0.56 & 0.52 \\
\hline 18 & $\mathrm{BrPe} 0008$ & $\begin{array}{l}\text { F:TTTTCAGCCTCCACTCTT } \\
\text { R:TACACCACCAACACTCAC }\end{array}$ & $(\mathrm{AG}) 9$ & 55 & 6 & $262-274$ & 0.70 & 0.75 & 0.63 \\
\hline 19 & $\mathrm{BrPe} 0025$ & $\begin{array}{l}\text { F:CAAGGAACCAGAACAAGAAGAA } \\
\text { R:GAAGAACAAGCCAGCCCA }\end{array}$ & $(\mathrm{GA}) 6$ & 55 & 9 & $108-130$ & 0.87 & 0.75 & 0.83 \\
\hline 20 & BrPe0039 & $\begin{array}{l}\text { F:GCTGCTCCACTGTGAATGTC } \\
\text { R:AACCTAGCCCCGTCACAGTA }\end{array}$ & $(\mathrm{AT}) 6$ & 60 & 2 & 195-197 & 0.43 & 0.14 & 0.33 \\
\hline 21 & $\mathrm{BrPe} 0050$ & $\begin{array}{l}\text { F:TCAAGGGTATCTTTGGTGCTG } \\
\text { R:AGCTTCAGCGAGACAAAACC }\end{array}$ & (TG)7 & 60 & 7 & $194-212$ & 0.58 & 0.21 & 0.54 \\
\hline 22 & $\mathrm{BrPe} 0013$ & $\begin{array}{l}\text { F:GATCGAGGTGAGGTACTG } \\
\text { R:GGTTTGGCTTTAATGGAGG }\end{array}$ & $(\mathrm{AG}) 8$ & 55 & 7 & 161-179 & 0.55 & 0.62 & 0.51 \\
\hline 23 & $\mathrm{BrPe} 0020$ & $\begin{array}{l}\text { F:TAAAGCATCAGGTCAG } \\
\text { R:TAGATAGATTTGACGGG }\end{array}$ & $(\mathrm{GT}) 7$ & 55 & 5 & 287-299 & 0.56 & 0.33 & 0.49 \\
\hline & Mean & & & & 6.39 & & 0.65 & 0.35 & 0.59 \\
\hline
\end{tabular}

Note. F: forward primer; R: reverse primer; Ta: annealing temperature; Ho: observed heterozygosity; He: expected heterozygosity; PIC: polymorphic information content.

Genetic dissimilarities ranged from 0.067 to 1.00 . The maximum distance (1.00) was observed between an accession of $P$. edulis "roxo típica" and $P$. caerulea (Table 1; accessions 33 and 17, respectively); and between accession 'GX SB', 'PL1 MEAM-2', and P. incarnata in relation to the P. hatschbachii accession (Table 1, 
accessions 7, 9, 21, and 26, respectively). The lowest distance occurred between the hybrids 'PL3 $\times$ GA (T4R4PL1)' (accession 1) and 'ML2' (accession 3) in the BC2 and BC5 backcrossing stage, respectively (Table 1). The analysis of accessions with different degrees of dissimilarity is evidenced by the amplitude of the genetic distance values. Similar results were reported by Araya et al. (2017) in a collection of 28 accessions of six species of Passiflora ( $P$. edulis, P. alata, P. maliformis, P. nitida, P. quadrangularis, and P. setacea), based on SSR markers.

Clustering and graphical dispersion analyses evidenced the divergence among accessions (Figure 1). Clustering analyses also showed the formation of four similarity groups and considered the genetic distance of 0.75 as the cutoff point.

The cophenetic correlation measures the fit degree between the dissimilarity matrix and the matrix obtained by the clustering method. A coefficient of cophenetic correlation of good magnitude $(r=0.85)$ was observed and evidenced the consistency in the adjustment between the graphic representation of the genetic similarity and its original matrix. Also, it ensures that inferences be made by visual evaluation of the dendrogram (Figure 1A).

The first group comprises passion fruit accessions originated from selection among and within progenies. By its turn, these progenies were obtained from interspecific crosses followed by backcrosses with commercial $P$. edulis. Therefore, plants from group 1 are genetically close to the recurrent parent (Table 1, accessions 1 to 16 , 18, and 20; Figure 1). This result suggests that the backcrossing cycles led to recurrent genome recovery. The SSR markers evidenced the genetic variability among accessions. This first group also included the MSC accession, a commercial $P$. edulis variety originated from mass selection, and the $P$. incarnata and $P$. caerulea accessions (Table 1, accessions 30, 21, and 17, respectively; Figure 1). Muschner et al. (2003) had already clustered $P$. edulis, $P$. incarnata, $P$. setacea, and $P$. caerulea by phylogeny molecular analyses in Passiflora species using polymorphisms of nrITS, trnL-trnF, and rps4. Paiva, Viana, Santos, Silva, \& Oliveira (2014b) also reported molecular similarity between $P$. edulis and P. setacea and between $P$. edulis and P. caerulea when using morphological and quantitative descriptors.

Although classified as P. edulis, the accessions of P. edulis "roxo típica" (Table 1; accessions 31, 32, and 33), did not cluster within the P. edulis group (Figure 1). In contrast, they were associated with a second group formed with the $P$. setacea accession (Table 1; accession 25). Similar results were recorded by Araya et al. (2017). Clustering of the accessions $P$. edulis Sims "flavicarpa" and $P$. edulis "roxo típica" were verified when using chloroplast DNA sequences (Belon, 2014). However, phylogenetic differences between these accessions were detected when ITS sequences were analyzed (Belon, 2014). These results suggest that future investigations should comprise a larger sample of $P$. edulis, including $P$. edulis "flavicarpa" and wild $P$. edulis Sims accessions. Recent analyses of the reproductive system of $P$. edulis "roxo típica" indicate that these accessions are preferentially autogamous, while those of $P$. edulis are mostly allogamous. These findings could probably explain the genetic distance among the accessions of passion fruit (Araya et al., 2017).

The third group included accessions of $P$. quadrifaria, P. hatschbachii, P. tholozanii, the P. hatschbachii $\times$. quadrifaria hybrid, and the BRS Rosa Púrpura cultivar (Table 1, accessions 28, 26, 29, 27, and 23, respectively). This result confirms the hybridization and genealogy of these hybrids. The species $P$. tholozanii and $P$. quadrifaria belong to the Distephana supersection. The systematic review study performed by Feuillet \& MacDougal (2003) incorporated the subgenus Distephana, currently considered a supersection, to the subgenus Passiflora.

The fourth and last group is formed by a single accession of the species $P$. aff. amethystina "macrocarpa". The phylogenetic tree of 43 Passiflora species based on chloroplast and ITS DNA sequences obtained by Bellon (2014) grouped three accessions of $P$. amethystina ( $P$. amethystina "verdadeira", $P$. amethystina "SP", and $P$. amethystina "macrocarpa"). An accession of P. caerulea was also grouped within this phylogenetic Passiflora subgenus group. In this work, although $P$. amethystina "macrocarpa" and $P$. caerulea accessions did not cluster together, the latter was one with highest similarity to the $P$. amethystina accession $(0.78)$, together with the accessions 'MEAM-1' and P. tholozanii. 


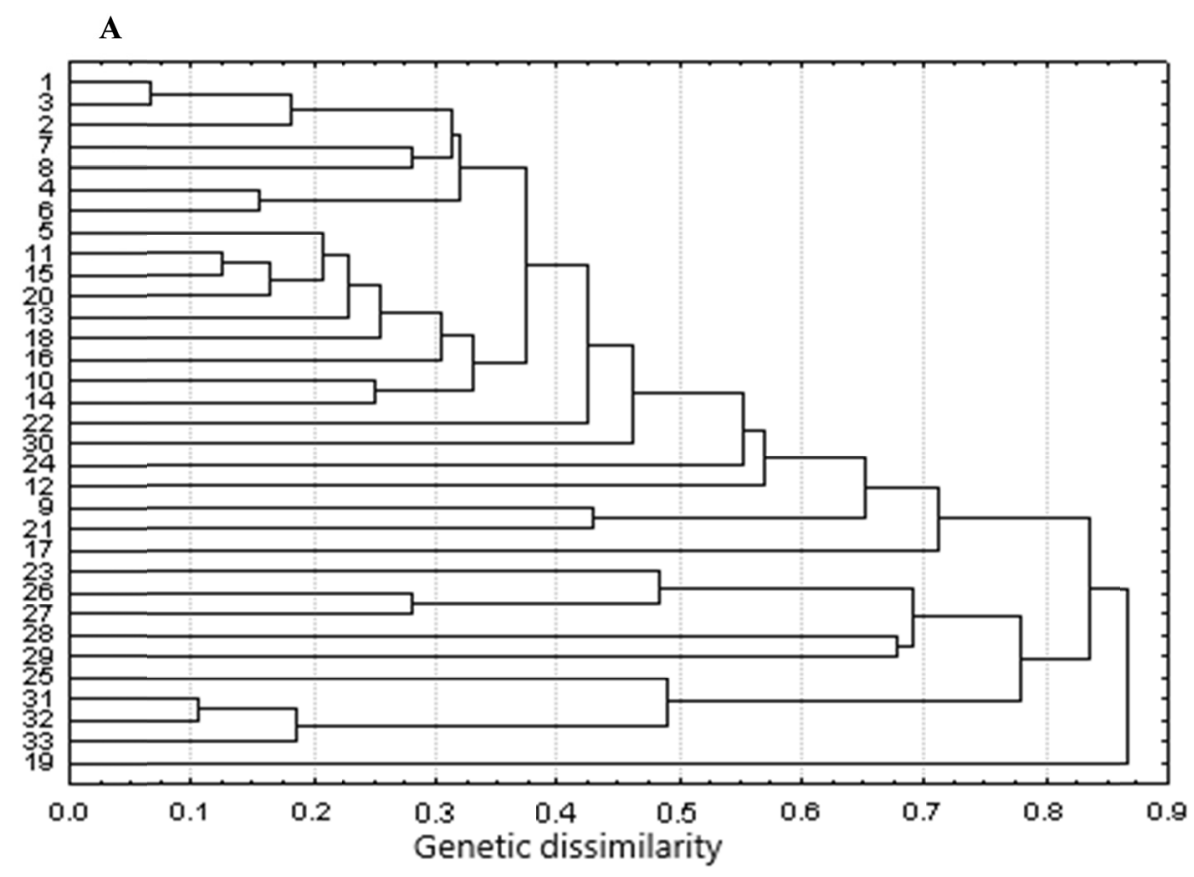

$\mathbf{B}$

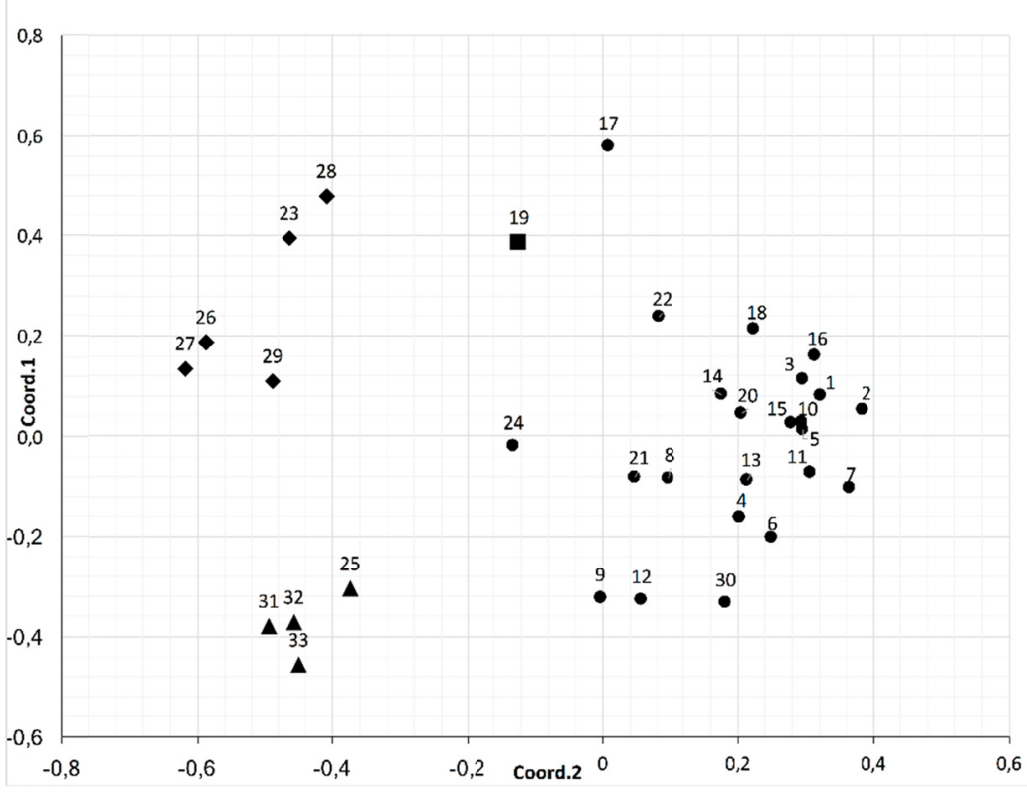

Figure 1. Clustering (A) and graphical dispersion (B) analyses of 33 Passiflora spp. accessions based on the genetic dissimilarity matrix and using 23 SSR markers. The UPGMA method was used as a clustering criterion.

The principal coordinates method was used in graphical dispersion analysis. The coefficient of cophenetic correlation (r) was 0.85. Legend: 1-PL 3 × GA, 2 (T4R4P1); 2-ML 1; 3- ML2; 4-PL2; 5-MEAM-3; 6-GX DF; 7-GX SB; 8-PL6; 9-PL 1 MEAM-2; 10-PL 4 (Longão flor azul); 11- PL 3; 12-PL 5; 13-LD3; 14-325; 15-LD4; 16-Vermelhão; 17-P. caerulea; 18-MEAM-1; 19-P. aff. Amethystina; 20-P. edulis $\times$ P. incarnata; 21-P. incarnata; 22-Rosa Púrpura $\times P$. edulis; 23-Rosa Púrpura; 24-P. setacea $\times P$. edulis; 25-P. setacea; 26- $P$. hatschbachii; 27-P. hatschbachii $\times$ P. quadrifaria; 28-P. quadrifaria; 29-P. tholozanii; 30-MSC; 31-P. edulis "roxo típica" (PL1);

32-P. edulis "roxo típica" (PL2); 33-P. edulis "roxo típica" (PL3).

Group $1(\bullet)$; group $2(\bullet)$; group $3(\bullet)$; and group 4 ( 


\section{Conclusions}

The SSR markers demonstrated high genetic variability among the studied accessions and indicated the efficiency of the recurrent genome recovery in the backcross program.

The genetic structure among the accessions showed the clustering tendency between the wild accessions of $P$. hatschbachii and $P$. quadrifaria and the accessions obtained from crossings involving these species. Similar results were observed for $P$. incarnata and $P$. edulis accessions. Therefore, the hybridization and genealogy of these accessions were confirmed.

The knowledge generated in this study provides information on the diversity of the multispecific hybrids and their respective wild parents. Therefore, it will contribute to breeding programs when selecting the best crosses.

\section{Acknowledgements}

This research was supported by Embrapa - Project number 22.16.04.007.00. This study was also financed, in part, by the Coordenação de Aperfeiçoamento de Pessoal de Nível Superior-Brazil (CAPES)-Finance Code 001. We are thankful for technical support and assistance of MSc. Lorena Ramos da Mata, MSc. Wellington Bruno dos Santos Alves, and Zilneide Pedrosa de Souza Amaral. A special acknowledgement to Dr. Dario Grattapaglia for providing research, facility and material support for this work.

\section{References}

Abreu, S. D. P. M., Peixoto, J. R., Vilela, N. T., \& De Figueiredo, M. A. (2009). Características agronômicas de seis genótipos de maracujazeiro-azedo cultivados no Distrito Federal. Revista Brasileira de Fruticultura, 31(3), 920-924. http://doi.org/10.1590/S0100-29452009000300042

Araya, S., Martins, A. M., Junqueira, N. T. V., Costa, A. M., Faleiro, F. G., \& Ferreira, M. E. (2017). Microsatellite marker development by partial sequencing of the sour passion fruit genome (Passiflora edulis Sims). BMC Genomics, 18, 549. https://doi.org/10.1186/s12864-017-3881-5

Aukar, A. P. A., Lemos, E. G. M., \& Oliveira, J. C. (2002). Genetic variations among passion fruit species using RAPD markers. Revista Brasileira de Fruticultura, 24(3), 738-740. https://doi.org/10.1590/S010029452002000300044

Bellon, G. (2014). Filogenia, variabilidade genética e caracterização de Passiflora silvestres, comerciais e híbridos interespecíficos como fontes de resistência a doenças (Doctoral Dissertation, University of Brasilia, Brasília, Brazil). Retrieved from http://repositorio.unb.br/handle/10482/15872

Bellon, G., Faleiro, F. G., Junqueira, K. P., Junqueira, N. T. V., Santos, E. C., Braga, M. F., \& Guimarães, C. T. (2007). Variabilidade genética de acessos silvestres e comerciais de Passiflora edulis Sims. com base em marcadores RAPD. Revista Brasileia de Fruticultura, 29(1), 124-127. https://doi.org/10.1590/S0100-29452 007000100027

Bernacci, L. C., Vitta, F. A., \& Bakker, Y. V. (2003). Passifloraceae. In M. G. L. Wanderley, G. J. Shepperd, \& A. M. Giulietti (Eds.), Flora fanerogâmica do estado de São Paulo (pp. 247-274). São Paulo: Instituto de Botânica. http://botanica.sp.gov.br/files/2016/02/Passifloraceae.pdf

Botstein, D., White, R., Skolnick, M., \& Davis, R. (1980). Construction of a genetic linkage map in man using restriction fragment length polymorphisms. American Journal of Human Genetics, 32(3), 314-331. https://www.ncbi.nlm.nih.gov/pmc/articles/PMC1686077/

Castro, A. P. G., Faleiro, F. G., Carvalho, D. D. C., Fonseca, K. G., Vilela, M. F., Junqueira, N. T. V., \& Cares, J. E. (2011). Genetic variability of Passiflora spp. from commercial fields in the Federal District, Brazil. Ciência Rural, 41(6), 996-1002. https://doi.org/10.1590/S0103-84782011000600013

Cerqueira-Silva, C. B. M., Cardoso-Silva, C. B., Santos, E. S. L., Conceição, L. D. H. C. S., Pereira, A. S., Oliveira, A. C., \& Corrêa, R. X. (2010). Genetic diversity in wild species of passion fruit (Passiflora trintae) based on molecular markers. Genetics and Molecular Research, 9(4), 2123-2130. https://doi.org/ 10.4238/vol9-4gmr875

Cerqueira-Silva, C. B. M., Moreira, C. N., Figueira, A. R., Corrêa, R. X., \& Oliveira, A. C. (2008). Detection of a resistance gradient to passion fruit woodiness virus and selection of "yellow" passion fruit plants under field conditions. Genetic Molecular Research, 7(4), 1209-1216. https://doi.org/10.4238/vol7-4gmr484

Cerqueira-Silva, C. B., Santos, E. S. L., Vieira, J. G. P., Mori, G. M., Jesus, O. N., Corrêa, R. X., \& Souza, A. P. (2014). New microsatellite markers for wild and commercial species of Passiflora (Passifloraceae) and cross-amplification. Applications in Plant Sciences, 2, 1300061. https://doi.org/10.3732/apps.1300061 
Cerqueira-Silva, C.B., Santos, E. S. L, Souza, A. M., Mori, G. M., Oliveira, E. J., Corrêa, R. X., \& Souza, A. P. (2012). Development and characterization of microsatellite markers for the wild South American Passiflora cincinnata (Passifloraceae). American Journal of Botany, 99(4), 170-172. https://doi.org/10.3732/ ajb. 1100477

Crochemore, M. L., Molinari, H. B. C., \& Vieira, L. G. E. (2003). Genetic diversity in passion fruit (Passiflora spp.) evaluated by RAPD markers. Brazilian Archives of Biology and Technology, 46(4), 521-527. https://doi.org/10.1590/S1516-89132003000400005

Cruz, C. D. (2013). Genes-A software package for analysis in experimental statistics and quantitative genetics. Acta Scientiarum Agronomy, 35(3), 271-276. https://doi.org/10.4025/actasciagron.v35i3.21251

Domaniç, N. O., \& Preparata, F. P. (2007). A novel approach to the detection of genomic approximate tandem repeats in the levenshtein metric. Journal of Computational Biology, 14(7), 873-891. https://doi.org/ 10.1089/cmb.2007.0018

Fajardo, D., Angel, F., Grum, M., Tohme, J., Lobo, M., Roca, W. M., \& Sanchez, I. (1998). Genetic variation analysis of the genus Passiflora L. using RAPD markers. Euphytica, 101(3), 341-347. https://doi.org/ 10.1023/A:1018395229851

Faleiro, F. G., Faleiro, A. S. G., Cordeiro, M. C. R., \& Karia, C. T. (2003). Metodologia para operacionalizar a extração de DNA de espécies nativas do cerrado. Planaltina, DF: Embrapa.

Feuillet, C., \& MacDougal, J. M. (2003). A new infrageneric classification of Passiflora L. (Passifloraceae). Passiflora, 13, 34-38. https://doi.org/10.2307/3393379

Holleley, C. E., \& Geerts, P. G. (2009). Multiplex manager 1.0: A cross-platform computer program that plans and optimizes multiplex PCR. BioTechniques, 46(7), 511-517. https://doi.org/10.2144/000113156

Imig, D. C., Milward-de-Azevedo, M. A., \& Cervi, A. C. (2018). Passifloraceae sensu stricto de Minas Gerais, Brasil Passifloraceae sensu stricto from Minas Gerais, Brazil. Rodriguésia, 69(4), 1701-1735. https://doi.org/10.1590/2175-7860201869415

Junqueira, N. T. V., Braga, M. F., Faleiro, F. G., Peixoto, J. R., \& Bernacci, L. C. (2005). Potencial de espécies silvestres de maracujazeiro como fonte de resistência a doenças. In F. G. Faleiro, N. T. V. Junqueira, \& M. F. Braga (Eds.), Maracujá: Germoplasma e melhoramento genético (Vol. 1, pp. 81-108). Planaltina, DF, Brazil: Embrapa Cerrados.

Krosnick, S. E., Ford, A. J., \& Freudenstein, J. V. (2009). Taxonomic revision of Passiflora subgenus Tetrapathea including the monotypic genera Hollrungia and Tetrapathea (Passifloraceae), and a new species of Passiflora. Systematic Botany, 34, 375-385. https://doi.org/10.1600/036364409788606343

Lim, K. G., Kwoh, C. K., Hsu, L. Y., \& Wirawan, A. (2013). Review of tandem repeat search tools: A systematic approach to evaluating algorithmic performance. Briefing in Bioinformatics, 14, 67-81. https://doi.org/ 10.1093/bib/bbs023

Litt, M., \& Luty, J. A. (1989). A hypervariable microsatellite revealed by in vitro amplification of a dinucleotide repeat within the cardiac muscle actin gene. The American Journal of Human Genetics, 44(3), 397-401.

Mäder, G., Zamberlan, P. M., Fagundes, N. J. R., Magnus, T., Salzano, F. M., Bonatto, S. L., \& Freitas, L. B. (2010). The use and limits of ITS data in the analysis of intraspecific variation in Passiflora L. (Passifloraceae). Genetics and Molecular Biology, 33(1), 99-108. https://doi.org/10.1590/S1415-4757200 9005000101

Marshall, T. C., Slate, J., Kruuk, L. E. B., \& Pemberton, J. M. (1998). Statistical confidence for likelihood-based paternity inference in natural populations. Molecular Ecology, 7(5), 639-655. https://doi.org/10.1046/ j.1365-294x.1998.00374.x

Matschiner, M., \& Salzburger, W. (2009). TANDEM: integrating automated allele binning into genetics and genomics workflows. Bioinformatics, 25(15), 1982-3. https://doi.org/10.1093/bioinformatics/btp303

Meletti, L. M. M., Soares-Scott, M. D., \& Bernacci, L. C. (2005). Caracterização fenotípica de três seleções de maracujazeiro-roxo (Passiflora edulis Sims). Revista Brasileira de Fruticultura, 27(2), $268-272$. https://doi.org/10.1590/S0100-29452005000200020

Muschner, V. C., Lorenz, A. P., Cervi, A. C., Bonatto, S. L., Souza-Chies, T. T., Salzano, F. M., \& Freitas, L. B. 2003 A first molecular phylogenetic analysis of Passiflora (Passifloraceae). American Journal of Botany, 90(8), 1229-1238. https://doi.org/10.3732/ajb.90.8.1229 
Oliveira E. J., Pádua J. G., Zucchi M. I., Camargo L. E., Fungaro M. H. P., \& Vieira M. L. C. (2005). Development and characterization of microsatellite markers from the yellow passion fruit (Passiflora edulis f. flavicarpa). Molecular Ecology Notes, 5(2), 331-333. https://doi.org/10.1111/j.1471-8286.2005.00917.x

Oliveira, E. J. (2006). Desenvolvimento e uso de marcadores microssatélites para construção e integração de mapas genéticos de maracujá-amarelo (Passiflora edulis Sims f. flavicarpa Deg.) (Doctoral Dissertation, University of São Paulo, São Paulo, Brazil).

Oliveira, J. da S., Faleiro, F. G., Junqueira, N. T. V., \& Viana, M. L. (2016). Genetic and morphoagronomic diversity of Passiflora spp. based on quantitative measurements of flowers and fruits. Revista Brasileira de Fruticultura, 39, (1)e-003. https://doi.org/10.1590/0100-29452017003

Oliveira, J. da S., Faleiro, F. G., Junqueira, N. T. V., Fonseca, K. G., \& Araya, S. (2019). Genetic Variability of Passiflora spp. based on ISSR and RAPD. Asian Journal of Science and Technology, 10(1), 9375-9378.

Ortiz, D. C., Bohórquez, A., Duque, M. C., Tohme, J., Cuéllar, D., \& Mosquera, V. T. (2012). Evaluating purple passion fruit (Passiflora edulis Sims F. edulis) genetic variability in individuals from commercial plantations in Colombia. Genetic Resources and Crop Evolution, 59(6), 1089-1099. https://doi.org/10.1007/ s10722-011-9745-y

Paikrao, H. M., Patil, A. S., Gaikwad, V. J., Dhore, R. D., Ambulkar, K., Ahirkar, K., \& Bande, S. N. (2010). Comparative phylogenetic analysis of Passiflora based on protein marker chloroplast expressed glutamine synthetase (ncpGS) and ribosomal protein S4 (rpS4). Journal of Advanced Bioinformatics Applications and Research, 1, 1-6.

Paiva, C. L., Viana, A. P., Santos, E. A., Silva, R. N. O., \& Oliveira, E. J. (2014b). Genetic diversity of the genus Passiflora using the Ward-MLM strategy. Revista Brasileira de Fruticultura, 36(2), 381-390. https://doi.org/10.1590/0100-2945-156/13

Paiva, C., Viana, A. P., Santos, E. A., Freitas, J. C. O., Silva, R. N. O., \& Oliveira, E. J. (2014a). Genetic variability assessment in the genus Passiflora by SSR marker. Chilean Journal of Agricultural Research, 74(3), 355-360. http://doi.org/10.4067/S0718-58392014000300015

Peréz, J. O., \& d'Eeckenbrugge, G. C. (2017). Morphological characterization in the genus Passiflora L.: An approach to understanding its complex variability. Plant Systematics and Evolution, 303(4), 531-558. https://doi.org/10.1007/s00606-017-1390-2

Plotze, R. O., Falvo, M., Pádua, J. G., Bernacci, L. C., Vieira, M. L. C., Oliveira, G. C. X., \& Bruno, O. M. (2005). Leaf shape analysis using the multiscale Minkowski fractal dimension, a new morphometric method: a study with Passiflora (Passifloraceae). Canadian Journal of Botany, 83, 287-301. https://doi.org/10.1139/ b05-002

Powell, W., Morgante, M., Andre, C., Hanafey, M., Vogel, S., Tingey, S., \& Rafalski, A. (1996). The comparision of RFLP, RAPD, AFLP and SSR (microsatellite) markers for germplasm analysis. Molecular Breeding, 2(3), 225-238. https://doi.org/10.1007/BF00564200

Quirino, T. R. (1998) Agricultura e meio ambiente: tendência. In M. A. Silveira, \& S. L. O. Vilela (Eds.). Globalização e sustentabilidade da agricultura (Vol. 15, pp. 109-138). Jaguariúna, Brazil: CNPMA.

Ramaiya, S. D., Bujang, J. S., \& Zakaria, M. H. (2014). Genetic diversity in Passiflora Species assessed by morphological and ITS sequence analysis. The Scientific World Journal, 2014, 1-11. https://doi.org/10.1155/ $2014 / 598313$

Santos, L. F., Oliveira, E. J., Silva, A. S., Carvalho, F. M., Costa, J. L., \& Pádua, J. G. (2011) ISSR markers as a tool for the assessment of genetic diversity in Passiflora. Biochemical Genetics, 49(7-8), 540-554. https://doi.org/10.1007/s10528-011-9429-5

SAS Institute Inc. (2008). SAS user's guide: Statistic (Version 9.1.3). Cary, NC, USA: SAS Institute Inc.

Segura, S., D’Eeckenbrugge, C. G., Bohorquez, A., Ollitrault, P., \& Tohme, J. (2002). An AFLP diversity study of the genus Passiflora focusing on subgenus Tacsonia. Genetic Resources and Crop Evolution, 49(2), 111-123. https://doi.org/10.1023/A:1014731922490

Segura, S., D’Eeckenbrugge, C. G., López, L., Grum, M., \& Guarino, L. (2003). Mapping the potencial distribuction of five species of Passiflora in Andean countries. Genetic Resources and Crop Evolution, 50(6), 555-566. https://doi.org/10.1023/A:1024424012134 
StatSoft Inc. (2005). Statistica for Windows (data analysis software system) (Version 7.1). Tulsa, Oklahoma: StatSoft Inc. Retrieved from http://www.statsoft.com

Ulmer, T., \& MacDougal, J.M. (2004). Passiflora: Passion flowers of the world. Portland: Timber Press.

Vanderplank, J. (1996). Passion flowers. Cambridge: MIT Press.

Viana, A. J. C., Souza, M. M., Araújo, I. S., Corrêa, R. X., \& Ahnert, D. (2010). Genetic diversity in Passiflora species determined by morphological and molecular characteristics. Biologia Plantarum, 54(3), 535-538. https://doi.org/10.1007/s10535-010-0094-z

Viana, A. P., Pereira, T. N. S., Pereira, M. G., Souza, M. M., Maldonado, J. F. M., \& Amaral, A. T. (2003). Genetic diversity among yellow passion fruit commercial genotypes and among Passiflora species using RAPD. Revista Brasileira de Fruticultura, 25(3), 489-493. https://doi.org/10.1590/S0100-294520030003 00032

Yockteng, R., \& Nadot, S. (2004). Phylogenetic relationships among Passiflora species based on the glutamine synthetase nuclear gene expressed in chloroplast (ncpGS). Molecular Phylogenetics and Evolution, 31(1), 379-396. https://doi.org/10.1016/S1055-7903(03)00277-X

\section{Copyrights}

Copyright for this article is retained by the author(s), with first publication rights granted to the journal.

This is an open-access article distributed under the terms and conditions of the Creative Commons Attribution license (http://creativecommons.org/licenses/by/4.0/). 